\title{
UPAYA MENINGKATKAN PEMAHAMAN MATA PELAJARAN PKn MELALUI STRATEGI CARD SORT DAN SNOW BALLING SMP
}

\author{
Oleh: \\ Lumkhatun \\ Universitas Muhammadiyah Surakarta
}

\begin{abstract}
Abstrak
Tujuan umum penelitian ini adalah untuk meningkatkan pemahaman materi kedaulatan rakyat dan sistem pemerintahan di Indonesia dalam pembelajaran PKn pada siswa kelas VIII E SMP Negeri 2 Kartasura melalui penerapan strategi pembelajaran card sort dan snow balling. Subjek pelaksanaan tindakan adalah siswa kelas VIII E SMP Negeri 2 Kartasura yang berjumlah 38 siswa. Data penelitian ini dikumpulkan melalui informan atau nara sumber, tempat dan peristiwa berlangsungnya aktifitas pembelajaran dan dokumen atau arsip. Teknik pengumpulan data dengan menggunakan metode observasi dan wawancara. Penelitian ini menggunakan dua macam triangulasi, yang pertama triangulasi sumber data yang berupa informasi dari guru dan siswa tentang tindakan yang diterapkan, dan kedua triangulasi teknik atau metode pengumpulan data dari hasil observasi maupun wawancara. Analisis data dalam penelitian ini menggunakan teknik analisis interaktif. Prosedur dalam penelitian ini terdapat empat tahap yaitu perencanaan, pelaksanan, pengamatan dan refleksi. Hasil penelitian ini menunjukkan bahwa tingkat keaktifan siswa dalam proses pembelajaran PKn Materi kedaulatan rakyat dan sistem pemerintahan di kelas VIII E SMP Negeri 2 Kartasura sebelum dilaksanakan Penelitian Tindakan Kelas yaitu dari siswa yang memahami materi dalam menjawab pertanyaan atau aktif dalam pembelajaran hanya sebanyak 11 siswa atau 28,50\% dari jumlah keseluruhan. Setelah dilakukan tindakan yang disepakati yaitu dengan menerapkan strategi card sort dan snow balling pada proses pembelajaran diperoleh hasil yaitu siklus I meningkat menjadi 21 siswa atau 55,25\% dari jumlah keseluruhan dan siklus II diperoleh meningkat menjadi 31 siswa atau 81,50\% dari jumlah keseluruhan. Hasil penelitian ini sudah memenuhi indikator kinerja. Berdasarkan data hasil Penelitian Tindakan Kelas di atas maka hipotesis kinerja yang menyatakan "Diduga dari Penerapan Strategi Pembelajaran Card Sort dan Snow Balling dapat Meningkatkan Pemahaman Materi Kedaulatan Rakyat dan Sistem Pemerintahan di Indonesia dalam Pembelajaran PKn pada Siswa Kelas VIII E SMP Negeri 2 Kartasura, terbukti dan diterima kebenarannya. Lebih lanjut dapat dikatakan bahwa semakin sering menerapkan strategi card sort dan snow balling akan menyebabkan semakin tinggi pula pemahamn materi pada siswa. Dengan demikian strategi card sort dan snow balling merupakan faktor yang ikut mempengaruhi pemahamn materi pada siswa dalam proses pembelajaran PKn materi kedaulatan rakyat dan sistem pemerintahan di Indonesia
\end{abstract}

Kata Kunci: Strategi pembelajaran, Card Sort dan Snow Balling, Pemahaman Materi, Kedaulatan Rakyat dan Sistem Pemerintahan di Indonesia 


\section{Pendahuluan}

Pendidikan adalah usaha sadar yang dengan sengaja dirancang untuk mencapai tujuan yang telah ditetapkan. Pendidikan bertujuan untuk meningkatkan kualitas sumber daya manusia, salah satu usaha untuk meningkatkan kualitas sumber daya manusia ialah melalui proses pembelajaran di sekolah. Guru sebagai pengajar sebaiknya tidak mendominasi kegiatan pembelajaran tetapi membantu menciptakan kondisi yang mendukung serta memberikan motivasi dan bimbingan kepada siswa agar dapat mengembangkan potensi dan kreatifitasnya melalui kegiatan belajar. Peran guru adalah sebagai sumber belajar, fasilitator, pengelola, demonstrator, pembimbing, dan evaluator. Sebagai motivator guru harus mampu membangkitkan motivasi siswa agar aktivitas siswa dalam proses pembelajaran berhasil dengan baik dan siswa dapat memahami materi dengan mudah.

Proses pembelajaran di kelas sering kali menghadapi banyak permasalahan. Salah satunya adalah kurangnya pemahaman materi dari siswa. Pemahaman siswa merupakan sebuah bentuk penguasaan materi dan prestasi dari siswa bisa tercapai. Materi Kedaulatan Rakyat dan Sistem Pemerintahan di Indonesia merupakan salah satu materi mata pelajaran PKn yang dipelajari di SMP kelas VIII semester II di SMP Negeri 2 Kartasuara Kabupaten Sukoharjo. Pemahaman siswa tentang materi Kedaulatan Rakyat dan Sistem Pemerintahan di Indonesia sangat kurang. Hal ini dikarenakan siswa tidak memperhatikan guru, siswa beranggapan bahwa mata pelajaran PKn itu dianggap mudah dan tidak perlu dipelajari secara mendalam karena tidak masuk dalam mata pelajaran yang diujikan dalam UNAS padahal dalam kenyataannya banyak siswa yang tidak bisa memenuhi Kriteria Ketuntasan Minimal (KKM). Jumlah siswa dalam kelas VII E adalah 38 siswa, dari siswa tersebut hanya 11 orang yang sudah sesuai dengan KKM. Sementara itu sebanyak 27 siswa masih belum sesuai dengan KKM. Keadaan tersebut diperparah oleh kurangnya kreativitas guru dalam menggunakan strategi pembelajaran. Untuk mengatasi permasalahan tersebut guru telah mencoba berbagai strategi pembelajaran. Strategi yang telah dilaksanakan guru selama ini diantaranya adalah ceramah dan penugasan. Beberapa strategi tersebut dirasa kurang efektif dalam meningkatkan pemahaman siswa. Pada saat guru menerangkan siswa hanya mendengarkan penjelasan guru, ada yang memperhatikan dan ada pula yang melakukan aktivitas lain misalnya: mengobrol dengan teman sebangkunya, mencoretcoret buku, bahkan ada yang tidur. Sementara itu, ketika guru memberi tugas siswa kurang sungguh-sungguh dalam mengerjakannya. Melihat kelemahan pada strategi pembelajaran yang 
telah diterapkan, maka guru mencoba memakai strategi lain yaitu metade diskusi dirumah, tetapi hasinya juga belum maksimal. Penggunaan metode ceramah dan penugasan dirasa tidak berhasil. Oleh karena itu, perlu dilakukan tindakan kelas lain yang diharapkan mampu meningkatkan pemahaman siswa tentang materi Kedaulatan Rakyat dan Sistem Pemerintahan di Indonesia. Solusi alternatif yang ditawarkan adalah dengan penerapan strategi card sort dan snow balling. Dengan penggunaan strategi card sort dan snow balling ini siswa dituntut untuk mendemonstrasikan suatu peran tertentu yang terkait dengan materi pelajaran. Dengan begitu siswa akan lebih memahami materi yang sedang dipelajari. Berdasarkan latar belakang masalah yang telah dikemukakan di atas maka dipandang cukup penting untuk mengadakan penelitian tindakan kelas tentang “Upaya Meningkatkan Pemahaman Materi Kedaulatan Rakyat dan Sistem Pemerin-tahan di Indonesia Melalui Penerapan Strategi Card Sort dan Snow Balling dalam Pembelajaran PKn pada Siswa Kelas VIII E SMP Negeri 2 Kartasura Kabupaten Sukoharjo.

\section{Kajian Teori}

\section{Kajian Mengenai Strategi Card Sort}

a. Pengertian Strategi Card Sort. Menurut Zaini dkk (2008:50) strategi card sort (sotir kartu) "merupakan kegiatan kolaboratif yang bisa digunakan untuk mengajarkan konsep, karakteristik, klasifikasi, fakta, tentang obyek atau mereview informasi”.

b. Langkah-langkah Pelaksanaan Strategi Card Sort. Menurut Zaini dkk (2008:50). Langkahlangkah strategi card sort (sotir kartu) sebagai berikut:

1) Setiap peserta didik diberi potongan kertas yang berisi informasi atau contoh yang tercakup dalam satu atau lebih kategori.

2) Mintalah peserta didk untuk bergerak dan berkeliling didalam kelas untuk menemukan kartu dengan kategori yang sama. (Anda dapat menggumumkan kategori tersebut sebelumnya atau membiyarkan peserta didik menemukan sendiri.

3) Peserta didik dengan kategori yang sama diminta mempresentasikan kategori masingmasing di depan kelas.

4) Seiring dengan presentasi dari tiap-tiap karegori tersebut, berikan poin-poin penting terkait materi pelajaran. 


\section{Kajian Mengenai Strategi Snow Balling}

a. Pengertian Strategi Snow Balling. Strategi ini digunakan untuk mendapatkan jawaban yang dihasilkan dari diskusi peserta didik secara bertingkat. Dimulai dari kelompok kecil kemudian dilanjutkan dengan kelompok yang lebih besar sehingga pada akhirnya akan memunculkan dua atau tiga jawaban yang telah disepakati oleh peserta didik secara berkelompok (Zaini dkk ,2008:58).

b. Langkah-langkah Pelaksanaan Strategi Snow Balling. Menurut Zaini dkk (2008: 58). Langkah-langkah strategi snow balling (bola salju) sebagai berikut:

1) Sampaikan topik materi yang akan diajarkan.

2) Minta peserta didik untuk menjawab secara berpasangan (dua orang)

3) Setelah peserta didik yang bekerja berpasangan tadi mendapatkan jawaban, pasangan tadi digabungkan dengan pasangan disampingnya. Dengan ini terbentuk kelompok dengan anggota empat orang.

4) Kelompok berempat ini mengerjakan tugas yang sama seperti dalam kelompok dua orang. Tugas ini dapat dilakukan dengan membandingkan jawaban kelompok dua orang dengan kelompok yang lain. Dalam langkah ini perlu ditegaskan bahwa jawaban kedua kelompok harus disepakati oleh semua anggota kelompok baru.

5) Setelah kelompok berempat ini selesai mengerjakan tugas, setiap kelompok digabungkan dengan satu kelompok yang lain. Dengan ini muncul kelompok baru yang anggotanya delapan orang.

6) Yang dikerjakan oleh kelompok baru ini sama dengan tugas pada langkah keempat diatas. Langkah ini dapat dilanjutkan sesuai dengan jumlah peserta didik atau waktu yang tersedia.

7) Masing-masing kelompok diminta menyampaikan hasilnya kepada kelas.

8) Pengajar akan membandingkan jawaban dari masing-masing kelompok kemudian memberikan usulan-usulan dan penjelasan-penjelasan secukupnya sebagai klasifikasi dari jawaban peserta didik.

c. Langkah-langkah Pelaksanaan Kolaborasi Strategi Card Sort dan Snow Balling. Setelah pelaksanaan strategi card sort selasai maka dilanjutkan dengan snow balling dengan langkahlangkah sebagai berikut:

1) Setiap peserta didik diberi potongan kertas yang berisi informasi. 
2) Mintalah peserta didik untuk bergerak dan berkeliling didalam kelas untuk menemukan kartu dengan kategori yang sama.

3) Peserta didik dengan kategori yang sama diminta mempresentasikan kategori masingmasing di depan kelas.

4) Peserta didik sudah membentuk beberapa kelompok sesuai dengan kategori.

5) Selanjutnya dengan strategi snow balling, guru menyampaikan topik materi yang akan diajarkan Minta peserta didik untuk menjawab secara berkelompok sesuai dengan kategori dari pelaksanaan strategi card sort tadi.

6) Setelah peserta didik yang bekerja sesuai dengan kategori mendapatkan jawaban, kelompok satu digabungkan dengan kelompok disampingnya. Dengan ini maka terbentuk kelompok dengan anggota yang lebih banyak.

7) Kelompok baru ini mengerjakan tugas yang sama seperti dalam kelompok yang tadi. Tugas ini dapat dilakukan dengan membandingkan jawaban kelompok yang tadi dengan kelompok yang lain. Dalam langkah ini perlu ditegaskan bahwa jawaban kedua kelompok harus disepakati oleh semua anggota kelompok baru.

8) Setelah kelompok baru ini selesai mengerjakan tugas, setiap kelompok digabungkan dengan satu kelompok yang lain lagi. Dengan ini muncul kelompok baru yang anggotanya lebih banyak.

9) Yang dikerjakan oleh kelompok baru ini sama dengan tugas pada langkah keempat delapan.

10) Masing-masing kelompok diminta menyampaikan hasilnya kepada kelas.

Berdasarkan kajian teoritis sebagaimana telah dipaparkan di atas, maka dalam penelitian ini perlu mangajukan anggapan dasar atau kerangka pemikiran sebagai berikut:

1. Penerapan strategi card sort dan snow balling akan meningkatkan pemahaman siswa tentang materi kedaulatan rakyat dan sistem pemerintahan di Indonesia.

2. Penerapan strategi card sort dan snow balling akan meningkatkan keaktifan siswa pada mata pelajaran PKn.

3. Penerapan strategi card sort dan snow balling akan meningkatkan prestasi belajar siswa pada mata pelajaran PKn. 


\section{Metode Penelitian}

Tempat penelitian ini adalah di SMP Negeri 2 Kartasura Kabupaten Sukoharjo Tahun 2010/2011. Tahap-tahap pelaksanaan kegiatan sejak persiapan sampai dengan penulisan laporan penelitian secara keseluruhan dilakukan selama kurang lebih empat bulan, yaitu sejak bulan Maret sampai dengan bulan Juni 2012. Subjek dalam penelitian ini adalah guru PKn kelas VIII E dan Kepala sekolah SMP Negeri 2 Kartasura Kabupaten Sukoharjo yaitu bertindak sebagai subjek yang memberikan tindakan dan membantu dalam memberikan izin dalam penelitian ini. Seluruh siswa kelas VIII E SMP Negeri 2 Kartasura sebagai subjek penelitian yang menerima tindakan. Peneliti sebagai subjek yang bertugas merencanakan, mengumpulkan data, menganalisis data, dan membuat kesimpulan penelitian.

Model penelitian tindakan kelas adalah: "secara garis besar terdapat empat tahapan yang harus dilalui, yaitu (1) perencanaan (2) pelaksanaan, (3) pengamatan, (4) refleksi. Data penelitian ini dikumpulkan dari berbagai sumber yang meliputi:

1. Informan atau nara sumber, yaitu guru dan siswa kelas VIII E SMP Negeri 2 Kartasura Kabupaten Sukoharjo.

2. Tempat dan peristiwa berlangsungnya aktivitas pembelajaran pada materi kedaulatan rakyat dan sistem pemerintahan di Indonesia dan aktivitas lain yang bertalian. Dalam hal ini lokasinya adalah SMP Negeri 2 Kartasura Kabupaten Sukoharjo.

Teknik pengumpulan data yang digunakan dalam penelitian ini adalah dengan teknik observasi dan wawancara.

\section{Hasil Penelitian dan Pembahasan}

Pembahasan terhadap permasalahan penelitian maupun hipotesis tindakan berdasarkan analisis data kualitatif hasil penelitian dari kolaboratif antara peneliti dan praktisi pendidikan dan tanggapan guru PKn yang terlibat dalam kegiatan ini, serta profil kelas sebelum dan sesudah penelitian yang dibuat oleh peneliti yang melakukan tindakan kerja kolaborasi dimulai dari: (1) perencanaan tindakan, (2) pelaksanaan tindakan, (3) pengamatan tindakan, (4) refleksi hasilnya sebagai berikut, tentang proses pembelajaran dengan strategi card sort dan snow balling dan hasil penelitian yang dilakukan secara kolaboratif antara peneliti dan guru kelas VIII E SMP Negeri 2 Kartasura Kabupaten Sukoharjo menyatakan bahwa dalam proses pembelajaran pada materi kedaulatan rakyat dan sistem pemerintahan di Indonesia dengan menggunakan strategi 
card sort dan snow balling telah memberikan dorongan kepada guru untuk mengembangkan strategi pembelajaran baru yang inovatif dalam melakukan pembelajaran yang mengikutsertakan peserta didik, sehingga dalam proses pembelajaran tidak berpusat pada guru dan peserta didik juga bisa bersosialisasi dengan peserta didik yang lainya.

Pembelajaran dengan menggunakan strategi card sort dan snow balling ini meminta peserta didik aktif berinteraksi dengan sesama temannya atau mencari pasangan kelompok sesuai kategori dan kerjasama kelompok, sehingga mereka lebih aktif dalam bertanya maupun berpendapat serta menjawab pertanyaan agar lebih mudah memahami materi dan terlibat langsung dalam proses pembelajaran. Berkaitan dengan adanya strategi card sort dan snow balling ini secara perlahan-lahan pemahaman peserta didik dalam proses pembelajaran mengalami peningkatan disetiap tindakan kelas yang dilakukan oleh peneliti. Peserta didik menjadi semakin paham dan aktif dalam menyampaikan pertanyaan atau pendapat serta menjawab pertanyaan disetiap mengikuti pelajaran. Oleh karena itu, siswa benar-benar memahami pengetahuan yang diberikan oleh guru sehingga pemahaman dalam materi ajar dapat maksimal. Strategi card sort dan snow balling dapat meningkatkan partisipasi dan pemahaman siswa secara optimal dalam pembelajaran materi kedaulatan rakyat dan sistem pemerintahan di Indonesia setelah peneliti dan guru kelas VIII E SMP Negeri 2 Kartaura Kabupaten Sukoharjo melakukan pembenahan pelaksanaan tindakan pada saat proses belajar mengajar. Pembenah-an tindakan tersebut adalah dengan mengaktifkan peserta didik untuk lebih terlibat dalam proses pembelajaran sehingga peserta didik lebih paham mengenai materi yang diajarkan. Pada awalnya, sebelum dilakukan tindakan pemahamn siswa hanya 11 siswa atau 28,95\% dari jumlah keseluruhan. Kemudian peneliti menerapkan strategi pembelajaran baru dalam proses pembelajaran yaitu dengan menggunakan strategi card sort dan snow balling.

Hasil dari penerapan strategi tersebut ternyata mampu meningkatkan pemahaman siswa pada siklus I dalam mengajukan pertanyaan dan berpendapat serta menjawab pertanyaan menjadi 21 siswa atau 55,25\% dari jumlah keseluruhan. Akan tetapi hasil pada siklus I ini belum mencapai indikator yang sudah ditentukan sebelumnya. Oleh karena itu peneliti mengadakan revisi dan evaluasi lagi untuk mendapatkan hasil yang optimal dan akhirnya peneliti melaksanakan siklus II dan didapatkan hasil 31 siswa atau 81,58\% dari jumlah keseluruhan yang paham materi untuk berani dan mampu mengajukan pertanyaan dan berpendapat serta menjawab pertanyaan. Untuk memahamkan peserta didik juga dilakukan penambahan pembimbing atau 
pengawas yang bertujuan untuk motivasi siswa agar siswa lebih aktif dalam proses pembelajaran sehingga peserta didik bisa lebih paham pada materi yang diajarkan. Melalui strategi card sort dan snow balling dapat terlihat bagaimana peningkatan pemahaman materi pada siswa dalam bertanya dan berpendapat serta menjawab pertanyaan, mulai dari sebelum penelitian hingga penelitian berakhir. Tingkat pemahaman materi pada siswa dalam bertanya dan berpendapat serta menjawab pertanyaan kelas VIII E SMP Negeri 2 Kartasura Kabupaten Sukoharjo yaitu sebanyak 11 siswa atau 28,95\% dari jumlah keseluruhan. Setelah dilakukan tindakan yang disepakati yaitu dengan menerapkan strategi card sort dan snow balling pada pembelajaran diperoleh hasil yaitu siklus I meningkat menjadi 21 siswa atau 55,25\% dari jumlah keseluruhan. Setelah dilakukan tindakan yang direvisi pada siklus II diperoleh hasil untuk jumlah siswa yang paham pada materi dalam aktif bertanya dan berpendapat serta menjawab pertanyaan meningkat menjadi 31 siswa atau 81,58\% dari jumlah keseluruhan. Pembelajaran tindakan kelas siklus II berjalan lebih baik jika dibandingkan dengan tindakan siklus I. Hasil yang dicapai juga meningkat, hal ini karena siswa sudah mengetahui tahap-tahap dalam strategi pembelajaran dengan strategi card sort dan snow balling. Gambar berikut adalah grafik perkembangan penerapan strategi card sort dan snow balling dalam upaya meningkatkan pemahaman materi pada siswa mulai dari kondisi awal sampai pada tindakan II.

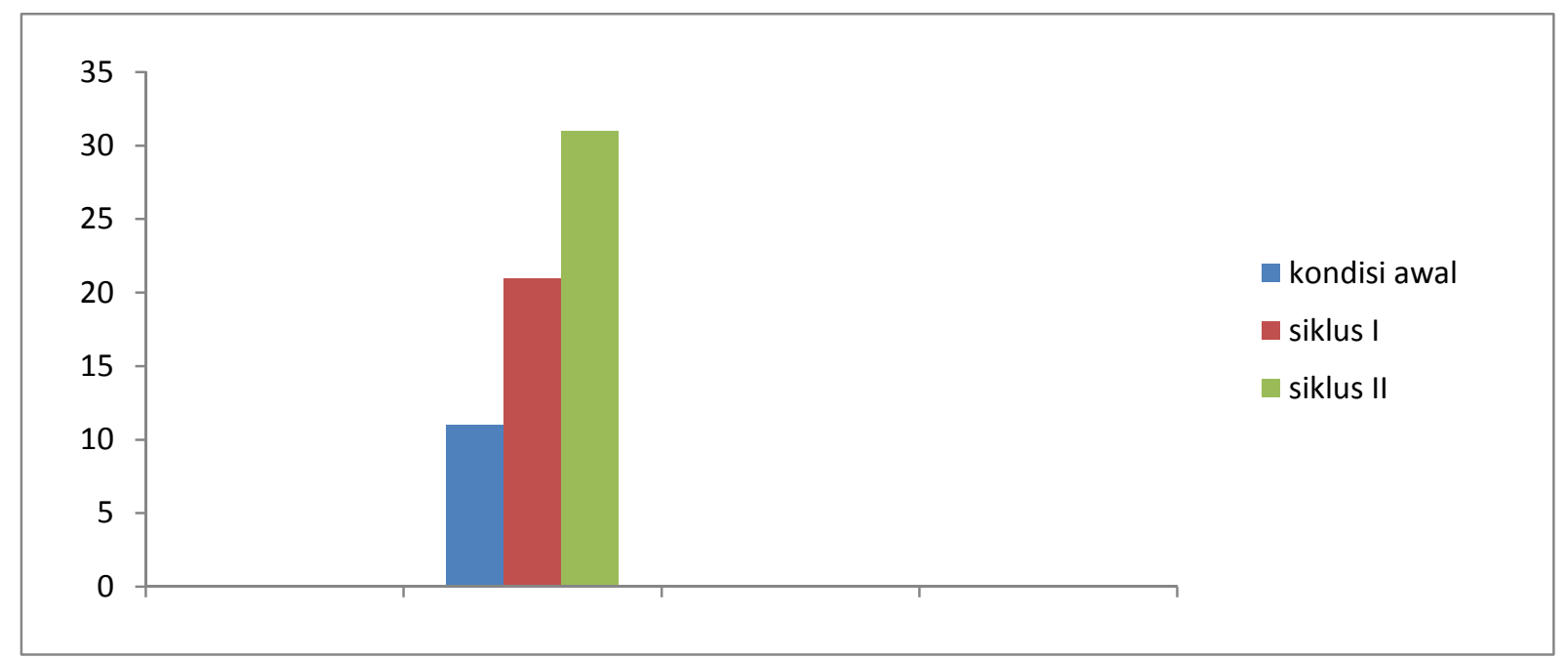

Gambar 4. Grafik Peningkatan Pemahaman Materi Pada Siswa Kelas VIII E SMP Negeri 2 Kartasura Secara Keseluruhan 


\section{Keterangan:}

1. Pemahaman siswa pada kondisi awal sebanyak 11 siswa atau $28,95 \%$ dari jumlah keseluruhan.

2. Pemahaman siswa pada siklus I sebanyak 21 siswa atau 55,25\% dari jumlah keseluruhan.

3. Pemahaman siswa pada siklus II sebanyak 31 siswa atau 81,58\% dari jumlah keseluruhan.

\section{Simpulan}

Dari rangkaian putaran penelitian tindakan kelas yang telah dilakukan terlihat adanya perubahan yang merupakan hasil penelitian dalam rangka usaha meningkatkan pemahaman materi kedaulatan rakyat dan sistem pemerintahan di Indonesia dalam pembelajaran PKn pada siswa kelas VIII E SMP Negeri 2 Kartasura Kabupaten Sukoharjo melalui penerapan strategi card sort dan snow balling. Bertitik tolak dari tindakan yang telah dilaksanakan pada penelitian ini, maka dapat diambil beberapa kesimpulan sebagai berikut:

1. Penerapan strategi card sort dan snow balling telah mampu meningkatkan pemahaman materi kedaulatan rakyat dan sistem pemerintahan di Indonesia dalam pembelajaran PKn pada siswa kelas VIII E SMP Negeri 2 Kartasura Kabupaten Sukoharjo Tahun 2010/2011 hingga sebanyak 31 siswa $(81,50 \%)$. Peningkatan pemahaman materi kedaulatan rakyat dan sistem pemerintahan di Indonesia diamati melalui kegiatan pembelajaran diskusi dan tes.

2. Pemahaman materi kedaulatan rakyat dan sistem pemerintahan di Indonesia dalam pembelajaran PKn pada siswa kelas VIII E SMP Negeri 2 Kartasura Kabupaten Sukoharjo Tahun 2010/2011 yaitu sebelum adanya penelitian siswa yang paham hanya 11 siswa $(28,95 \%)$. Pada putaran I sebanyak 21 siswa $(55,25 \%)$ dan pada putaran II sebanyak 31 siswa (81,58\%). Berdasarkan data tersebut maka dapat dilihat peningkatan sebesar 26,33\% dari putaran I ke putaran II. Sementara itu, secara keseluruhan dari kondisi awal, putaran I, dan putaran II mengalami peningkatan sebesar $52,63 \%$. 


\section{Daftar Pustaka}

Arikunto, Suharsimi. 2006. Prosedur Penelitian Suatu Pendekatan Praktik Edisi Refisi VI. Jakarta: Rineka Cipta.

Bakri, Noor Ms. 2009. Pendidikan Kewarganegaraan. Yogyakarta: Pustaka Pelajar.

Choiriyah, Nur. 2009. Penerapan Strategi Card Sort Pokok Materi Klasifikasi Makhluk Hidup Untuk meningkatkan Hasil Belajar Biologi Siswa Kelas VII E SMP Negeri 1 Karang Payung Kabupaten Grobogan Tahun Ajaran 2008/2009. http://perpustakaan.uns.ac.id. Diakses hari senin tanggal 28 Maret 2011 jam 09.30 WIB.

Creeswell, John. 2010. Research Design Pendekatan Kualitatif, Kuantitatif, Dan Mixed. Yogyakarta: Pustaka Belajar.

Departemen Pendidikan dan Kebudayaan. 1988. Kamus Besar Bahasa Indonesia Edisi Ketiga. Jakarta: Balai Pustaka.

Hamalik, Oemar. 1998. Kurukulum Dan Pembelajaran. Jakarta: Bumi Aksara.

Miles, B. Mathew dan Michael Huberman. 1992. Analisis Data Kualitatif (Buku Sumber tentang Metode-metode Baru). Jakarta: UIP.

Ratna, Nyoman Kutha. 2010. Metologi Penelitian Kajian Budaya Dan Ilmu Sosial Humaniora Pada Umumnya. Yogyakarta: Pustaka Belajar.

Purwensi dan Sri Hartati. 2010. Modul Pendidikan Kewarganegaraan SMP Kelas VIII Semerter Genab. Sokoharjo: Media Wiguna.

Pusat Bahasa Departemen Pendidikan Nasional. 2005. Kamus Besar Bahasa Indonesia Cetakan Pertama. Jakarta: Balai Pustaka.

Sagala, Syaiful. 2006. Konsep Dan Makna Pembelajaran. Bandung: Alfabeta.

Sudijono, Anas. 1996. Pengantar Evaluasi Pendidikan. Jakarta: Raja Grafindo Persada.

Zaini, Hisyam dkk. 2008. Strategi Pembelajaran Aktif. Yogyakarta: PT Pustaka Insan Madani. 